\title{
Plasma microRNA profiles: identification of miR-744 as a novel diagnostic and prognostic biomarker in pancreatic cancer
}

\author{
Mahito Miyamae ${ }^{1,3}$, Shuhei Komatsu ${ }^{\star}, 1,3$, Daisuke Ichikawa ${ }^{1}$, Tsutomu Kawaguchi $^{1}$, Shoji Hirajima ${ }^{1}$, \\ Wataru Okajima ${ }^{1}$, Takuma Ohashi ${ }^{1}$, Taisuke Imamura ${ }^{1}$, Hirotaka Konishi ${ }^{1}$, Atsushi Shiozaki ${ }^{1}$, Ryo Morimura ${ }^{1}$, \\ Hisashi Ikoma ${ }^{1}$, Toshiya Ochiai ${ }^{1}$, Kazuma Okamoto ${ }^{1}$, Hiroki Taniguchi ${ }^{2}$ and Eigo Otsuji ${ }^{1}$ \\ ${ }^{1}$ Division of Digestive Surgery, Department of Surgery, Kyoto Prefectural University of Medicine, 465 Kajii-cho, Kawaramachihir- \\ okoji, Kamigyo-ku, Kyoto 602-8566, Japan and 2 Department of Surgery, Kyoto Second Red Cross Hospital, 355-5 Kamanzadoori \\ Marutamachi Haruobicho, Kamigyo-ku, Kyoto 602-8026, Japan
}

Background: This study aims to explore novel microRNAs in plasma for screening cancer and predicting clinical outcomes in pancreatic cancer ( $\mathrm{PCa}$ ) patients using a microRNA array-based approach.

Methods: We used the Toray 3D-Gene microRNA array-based approach to compare plasma levels between PCa patients and healthy volunteers.

Results: (1) Six oncogenic microRNAs (miR-615-5p, -744, -575, -557, -675, and -550a) with high expression in plasma were selected. (2) By quantitative RT-PCR using plasma samples from 94 PCa patients and 68 healthy volunteers, a significantly higher level of plasma miR-744 in PCa patients than in healthy volunteers was validated in small-scale analysis $(P=0.0038)$, two independent cohort analyses, and large-scale analysis ( $P<0.0001$, AUC 0.8307). (3) miR-744 expression was significantly higher in PCa tissues $(P=0.0069)$ and $P C a$ cell lines $(P=0.0074)$ than in normal tissues and fibroblasts, respectively. Preoperative plasma level of miR-744 was significantly reduced in postoperative samples $(P=0.0063)$. (4) A high level of plasma miR-744, which was correlated with lymph node metastasis $(P=0.0407)$ and recurrences $(P=0.0376)$, was an independent poor prognostic factor of $P C a$ patients after pancreatectomy $(P=0.0007, \mathrm{HR} 21.2$ (3.17-436)). Furthermore, a high level of plasma miR-744 contributed to poorer progression-free survival of non-operable PCa patients who underwent gemcitabine-based chemotherapy $(P=0.0533)$. Overexpression of miR-744 in PCa cells induced significant chemoresistance to gemcitabine in vitro.

Conclusions: Plasma miR-744 might be useful biomarker for screening PCa, monitoring, and predicting poor prognosis and chemoresistance in PCa patients.

Pancreatic cancer (PCa) is the fifth leading cause of cancer death in Japan, the fourth leading cause of cancer-related death in the United States (Hirata et al, 2007; Jemal et al, 2009), and the eighth worldwide. Recent improvements in surgical techniques and perioperative management have reduced operation-related death during the perioperative period, and perioperative chemotherapy and radiotherapy have greatly improved; however, PCa still has extremely poor prognosis. Even now, the median survival time of PCa patients is 5-8 months and their 5-year survival rate is $<10 \%$, because PCa develops no symptoms, local invasiveness, and metastases to distant organs in the early stage of clinical course (Heinemann et al, 2008; Sultana et al, 2008; Jemal et al, 2009).

${ }^{*}$ Correspondence: Dr S Komatsu; E-mail: skomatsu@koto.kpu-m.ac.jp
${ }^{3}$ These authors contributed equally to this work.

Received 9 May 2015; revised 16 September 2015; accepted 23 September 2015; published online 27 October 2015

(C) 2015 Cancer Research UK. All rights reserved 0007-0920/15 
Curing PCa depends only on surgical resection with macroscopic tumour clearance by the most aggressive surgery among that for all digestive tract cancers. Nonetheless, $<20 \%$ of PCa patients receive the benefit of curative resection (Matsuno et al, 2004) (Yamamoto et al, 2012). Therefore, primary tumours must be detected at an early stage for the purpose of cure and improvement of survival rate, whereas patients with far advanced disease must be diagnosed preoperatively to avoid surgical impairments and to select appropriate chemotherapy to improve the quality of their residual life (Ozaka et al, 2012).

Because identifying clinical biomarkers and molecular targets for PCa may contribute to improving the survival rate of patients with this lethal disease, several studies attempted to detect the biological factors involved in the malignant potential of $\mathrm{PCa}$ (Jones et al, 2008; Thayer et al, 2003). In clinical settings, however, only a few molecules have been validated as diagnostic, therapeutic, and/or prognostic biomarkers for PCa. Conventional serum tumour markers, such as carcinoembryonic antigen and carbohydrate antigen 19-9 (CA19-9), have been used as convenient diagnostic assays (Satake et al, 1985) for early detection and monitoring the tumour status of PCa. These markers, however, lack sufficient sensitivity and specificity. Hence, the development of novel molecular biomarkers using less invasive technology is necessary, and it could allow clinicians to detect an early stage of $\mathrm{PCa}$, monitor tumour dynamics, and predict sensitivity to treatment and prognosis.

MicroRNAs (miRNAs), which are small non-coding RNAs, regulate the translation of specific protein-coding genes. Since their discovery in 1993 (Lee et al, 1993), miRNAs have been intensively studied in cancer research. Altered expression levels of miRNAs are related to several diseases and contribute to the development of various cancers (He et al, 2005; Calin and Croce, 2006; He et al, 2007; Lu et al, 2005). In recent years, several studies demonstrated that miRNAs are detectable in plasma/serum and present in a remarkably stable form (Calin and Croce, 2006; Mitchell et al, 2008; Chen et al, 2008; Filipowicz et al, 2008; Ichikawa et al, 2012). Tumour-derived miRNAs are resistant to endogenous ribonuclease activity in plasma/serum, because they bind to some proteins, such as the Argonaute 2 protein and high-density lipoproteins (Arroyo et al, 2011; Vickers et al, 2011), or are packaged by some kind of secretory vesicles, including apoptotic bodies and exosomes in plasma/serum (Hasselmann et al, 2001; Mitchell et al, 2008; Cocucci et al, 2009; Kosaka et al, 2010). The expression level of each miRNA in the serum is consistent in all healthy individuals (Chen et al, 2008; Mitchell et al, 2008). Furthermore, secretory particles, which contain specific miRNAs, can function as intercellular transmitters. For example, secreted miRNAs from donor cells can be transferred to and function in recipient cells (Valadi et al, 2007; Skog et al, 2008; Rechavi et al, 2009).

Concerning plasma/serum miRNAs in $\mathrm{PCa}$, several research groups, including our own, reported the potential utility of miRNAs that are circulating in plasma/serum in clinical application (Wang et al, 2009; Ho et al, 2010; Morimura et al, 2011; Liu et al, 2012; Kawaguchi et al, 2013). However, these miRNAs are not always candidates for $\mathrm{PCa}$, and more sensitive and promising candidates for screening cancer, monitoring tumour status, and predicting prognosis could be found in clinical settings. Therefore, we wished to find novel plasma miRNA candidates for detecting $\mathrm{PCa}$ and predicting clinical outcomes using a genome-wide miRNA array-based approach.

In this study, we selected six highly expressed oncogenic miRNA candidates (miR-615-5p, -744, -575, -557, -675, and -550a) through a plasma miRNA array-based approach and compared the plasma levels of each miRNA between PCa patients and healthy volunteers. We finally validated that the plasma miR-744 might be useful biomarker for screening $\mathrm{PCa}$, monitoring and predicting poor prognosis, and chemoresistance in PCa patients.
Our results provide evidence that the plasma level of miR-744 contributes to clinical decision making in PCa diagnosis and treatment to a clinically satisfactory degree.

\section{MATERIALS AND METHODS}

Patients and samples. The study was approved by the Institutional Review Board of both Kyoto Prefectural University of Medicine and Kyoto Second Red Cross Hospital, and each subject provided signed informed consent. Between January 2010 and April 2013, a total of 94 plasma samples of PCa patients and 68 samples of healthy volunteers were collected (Table 1). Ninety-four plasma samples from PCa patients consisted of 10 small-scale samples from Kyoto Prefectural University of Medicine, 55 validation samples from Kyoto Prefectural University of Medicine (1st cohort), and 29 validation samples from Kyoto Second Red Cross Hospital (second cohort). Sixty-eight samples from healthy volunteers consisted of 7 small-scale samples from Kyoto Prefectural University of Medicine, 39 validation samples from Kyoto Prefectural University of Medicine (first cohort), and 22 validation samples from Kyoto Second Red Cross Hospital (second cohort). From the patients who underwent surgery, a total of six PCa specimens were collected, as well as six normal tissue specimens from adjacent normal pancreatic tissues that were resected as a combined pancreatic resection for gastric cancer, in order to exclude any influence of atypical or precancerous status of pancreatic tissue on the analysis. These healthy volunteers included medical personnel and patients with benign disease, such as cholecystolithiais and inguinal hernia. These patients underwent medical examinations, including computed tomography and endoscopy, and were proved not to have any pancreatic or cancerous diseases. Tumour stages were assessed according to the Union for International Cancer Control classification (Sobin and Compton, 2010).

Table 1. Association between plasma miR-744 level and clinicopathological characteristics in patients with $\mathrm{PCa}$

\begin{tabular}{|c|c|c|c|}
\hline & & \multicolumn{2}{|c|}{ Plasma miR-744 } \\
\hline Variables & $n$ & Median & $P$-value ${ }^{a}$ \\
\hline Total & 94 & 50.7 & \\
\hline \multicolumn{4}{|l|}{ Gender } \\
\hline Male & 52 & 49.6 & \multirow[t]{2}{*}{0.3383} \\
\hline Female & 42 & 54.3 & \\
\hline \multicolumn{4}{|l|}{ Age, years } \\
\hline$<65$ & 35 & 74.6 & \multirow[t]{2}{*}{0.0807} \\
\hline$>65$ & 59 & 47.5 & \\
\hline \multicolumn{4}{|l|}{ Tumour location } \\
\hline $\mathrm{Ph}$ & 47 & 47.5 & \multirow[t]{3}{*}{0.1617} \\
\hline Pbt & 23 & 63.1 & \\
\hline $\mathrm{Ph}$ or Pbt with distant metastasis & 24 & 60.9 & \\
\hline \multicolumn{4}{|l|}{ T-stage } \\
\hline Tis/T1/T2 & 20 & 26.1 & \multirow[t]{2}{*}{0.0059} \\
\hline $\mathrm{T} 3 / \mathrm{T} 4 / \mathrm{TX}$ & 74 & 61.6 & \\
\hline \multicolumn{4}{|l|}{ N-stage } \\
\hline No & 41 & 49 & \multirow[t]{2}{*}{0.2988} \\
\hline N1/NX & 53 & 51.2 & \\
\hline \multicolumn{4}{|l|}{ M-stage (TNM) } \\
\hline MO & 70 & 50.7 & \multirow[t]{2}{*}{0.1464} \\
\hline $\mathrm{M} 1 / \mathrm{MX}$ & 24 & 60.9 & \\
\hline \multicolumn{4}{|c|}{ 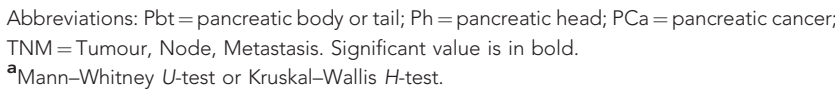 } \\
\hline
\end{tabular}


Peripheral blood $(7 \mathrm{ml})$ was obtained from each patient at the time of diagnosis or before surgery and from the healthy volunteers. The blood was transferred into sodium heparin tubes (BD Vacutainer, Franklin Lakes, NJ, USA) and immediately subjected to the three-spin protocol (1500 r.p.m. for $30 \mathrm{~min}$, 3000 r.p.m. for $5 \mathrm{~min}$, and 4500 r.p.m. for $5 \mathrm{~min}$ ) to prevent contamination by cellular nucleic acids. Plasma was collected and then stored at $-80^{\circ} \mathrm{C}$ until further processing. The resected specimens were fixed in formalin and embedded in paraffin for pathological diagnosis. Histological evaluation was performed for tissues adjacent to specimens, according to the criteria of the World Health Organisation. In all cases, two pathologists agreed with pathological observations and confirmed the diagnosis.

RNA extraction. Total RNA was extracted from $400 \mu \mathrm{l}$ of plasma using the mirVana PARIS Kit (Ambion, Austin, TX, USA) and finally eluted into $100 \mu \mathrm{l}$ of preheated $\left(95^{\circ} \mathrm{C}\right.$ ) Elution Solution according to the manufacturer's protocol. The reason why the volume of $400 \mu \mathrm{l}$ of plasma was used as the common denominator in each microarray analysis is that there was no definite internal control in plasma miRNA analyses as shown in our previous studies (Tsujiura et al, 2010; Komatsu et al, 2011; Morimura et al, 2011; Komatsu et al, 2012; Konishi et al, 2012; Hirajima et al, 2013; Kawaguchi et al, 2013; Komatsu et al, 2014). Total RNA was also extracted from four $15-\mu$ m-thick slices of the formalin-fixed and paraffin-embedded tissue (total $60 \mu \mathrm{m}$ in thickness) using the RecoverAll Total Nucleic Acid Isolation Kit (Ambion) and then eluted into $60 \mu \mathrm{l}$ of Elution Solution according to the manufacturer's protocol.

miRNA microarray analysis. Microarray analyses of the plasma samples were performed using the 3D-Gene miRNA microarray platform (Toray Industries, Kamakura, Japan; Nagino et al, 2006; Giovannetti et al, 2012; Konishi et al, 2012; Komatsu et al, 2014). The results were compared between three different PCa patients and three healthy volunteers. Namely, each $100 \mu \mathrm{l}$ plasma sample from three PCa patients, who underwent curative surgery, was equally mixed and totally $300 \mu$ l of plasma sample was used as a sample of PCa patients. On the other hand, each $100 \mu$ l plasma sample from three healthy volunteers was equally mixed and totally $300 \mu \mathrm{l}$ of plasma sample was used as a healthy volunteers' sample. RNA extraction and microarray analysis were performed according to the manufacturer's instructions described previously (Konishi et al, 2012). Briefly, the amount of total RNA in plasma was too small, and so $2-4 \mu \mathrm{l}$ of extracted total RNA from $300 \mu \mathrm{l}$ of plasma samples were used in the microarray experiments. This RNA was labelled with Hy5 using the Label IT miRNA Labeling Kit (Takara Bio, Otsu, Japan) and hybridised at $32{ }^{\circ} \mathrm{C}$ for $16 \mathrm{~h}$ on the $3 \mathrm{D}$-Gene chip. The 3D-Gene miRNA microarray (Human_miRNA_17v1.0.0, Toray Industries) can mount $>1500$ miRNAs based on the Human miRNA Version17 of MirBase (http://microrna.sanger.ac.uk/). The microarray was scanned, and the images obtained were numerated using the 3D-GeneH scanner 3000 (Toray Industries). The expression level of each miRNA was globally normalised using the background-subtracted signal intensity of the entire set of miRNAs in each microarray. The obtained microarray images were analysed using GenePix Pro (Molecular Devices, Sunnyvale, CA, USA).

Quantification of miRNA by qRT-PCR. The amounts of miRNAs were quantified by qRT-PCR using the human TaqMan MicroRNA Assay Kit (Applied Biosystems, Foster City, CA, USA). The reverse transcription reaction was carried out with a TaqMan MicroRNA Reverse Transcription Kit (Applied Biosystems) in $5 \mu \mathrm{l}$ of solution containing $1.67 \mu \mathrm{l}$ of extracted RNA, $0.05 \mu \mathrm{l}$ of $100 \mathrm{mM}$ dNTPs, $0.33 \mu \mathrm{l}$ of Multiscribe Reverse Transcriptase $\left(50 \mathrm{U}^{-1}\right)$, $0.5 \mu \mathrm{l}$ of $10 \times$ Reverse Transcription Buffer, $0.06 \mu \mathrm{l}$ of RNase inhibitor $\left(20 \mathrm{U}_{\mu} \mathrm{l}^{-1}\right), 1 \mu \mathrm{l}$ of gene-specific primer (hsa- miR-615-5p,
Assay ID: 002353; hsa-miR-744, Assay ID: 002324; hsa-miR-575, Assay ID: 001617; hsa-miR-557, Assay ID: 001525; hsa-miR-675, Assay ID: 002005; hsa-miR-550a, Assay ID: 002410; cel-miR-39, Assay ID: 000200; and RNU6B, Assay ID: 001093), and $1.39 \mu \mathrm{l}$ of nuclease-free water. To synthesise cDNA, reaction mixtures were incubated at $16^{\circ} \mathrm{C}$ for $30 \mathrm{~min}$, at $42{ }^{\circ} \mathrm{C}$ for $30 \mathrm{~min}$, and at $85{ }^{\circ} \mathrm{C}$ for $5 \mathrm{~min}$, and then were held at $4{ }^{\circ} \mathrm{C}$. Next, $0.67 \mu \mathrm{l}$ of cDNA was amplified using $5 \mu$ of TaqMan $2 \times$ Universal PCR Master Mix with no AmpErase UNG (Applied Biosystems), $0.5 \mu \mathrm{l}$ of gene-specific primers/probe, and $3.83 \mu \mathrm{l}$ of nuclease-free water in a final volume of $10 \mu \mathrm{l}$. Quantitative PCR was run on a StepOnePlus PCR system (Applied Biosystems), and reaction mixtures were incubated at $95^{\circ} \mathrm{C}$ for $10 \mathrm{~min}$, followed by 40 cycles of $95^{\circ} \mathrm{C}$ for $15 \mathrm{~s}$ and $60^{\circ} \mathrm{C}$ for $1 \mathrm{~min}$. Cycle threshold $(\mathrm{Ct})$ values were calculated with the StepOne Software v2.0 (Applied Biosystems).

As previously reported (Mitchell et al, 2008), we used an approach for data normalisation based upon spiking the sample with a synthetic RNA oligonucleotide, cel-miR-39, which does not exist in the human genome. C. elegans cel-miR-39 was purchased as a custom-made RNA oligonucleotide (Qiagen, Valencia, CA, USA). The oligo used for spiking, as a mixture of $25 \mathrm{fmol}$ of oligonucleotide in $5 \mu \mathrm{l}$ of total volume of water, was introduced after the addition of $2 \times$ Denaturing Solution (Ambion) to the plasma or serum sample to avoid degradation by endogenous plasma RNases. As a control for each RNA sample, cel-miR-39 was used for TaqMan qRT-PCR assays (Applied Biosystems) as described earlier. We normalised the data across samples using the $2^{-\Delta \Delta \mathrm{Ct}}$ method relative to cel-miR-39, whereas the expression of miRNAs from tissue samples and cultured cells was normalised using the $2^{-\Delta \Delta \mathrm{Ct}}$ method relative to U6 small nuclear RNA (RNU6B). $\Delta$ Ct was calculated by subtracting the $\mathrm{Ct}$ values of celmiR-39 or RNU6B from those of the miRNAs of interest. $\Delta \Delta \mathrm{Ct}$ was then calculated by subtracting the mean of $\Delta \mathrm{Ct}$ of plasma of healthy volunteer or normal pancreatic tissue from the $\Delta \mathrm{Ct}$ of $\mathrm{PCa}$ tissues. The change in gene expression was calculated with the equation $2^{-\Delta \Delta \mathrm{Ct}}$ (Livak and Schmittgen, 2001; Pfaffl, 2001).

Culture of PCa cell lines. Pancreatic cancer cell lines, PK-45H, PANC-1, PK-59, KP4-1, and PK-1, were purchased from RIKEN Cell Bank (Tsukuba, Japan) and cultured in Roswell Park Memorial Institute (RPMI)-1640 medium (Sigma, St Louis, MO, USA) supplemented with 10\% FBS (Trace Scientific, Melbourne, Australia). All cell lines were cultured in 5\% carbon dioxide at $37^{\circ} \mathrm{C}$ in a humidified chamber.

Transfection of a PCa cell line with miRNA. For overexpression of miR-744, the miR-744 mimic (Assay ID: MC13027) or control mimic microRNA (mirVana miRNA mimic Negative Control \#1), both of which were selected from the mirVana miRNA mimic panel (Ambion), was used to transfect KP4-1 cells with a final concentration of $12 \mu \mathrm{M}$, using Lipofectamine RNAiMAX (Invitrogen) according to the manufacturer's instructions. After $120 \mathrm{~h}$, the overexpression of miR-744 was confirmed by qRT-PCR using the human TaqMan MicroRNA Assay Kit (Applied Biosystems).

Cell viability assays. To assess the chemoresistance of a PCa cell line to gemcitabine, KP4-1 cells that were transfected with miR-744 or its control were plated onto a 24 -well plate $\left(1 \times 10^{4}{\left.\text { cells } \mathrm{ml}^{-1}\right)}^{-1}\right.$ and incubated overnight under normal culture conditions. The cells were then incubated with various concentrations of gemcitabine $(0.01,0.1,1,10$, or $100 \mu \mathrm{M})$. After $96 \mathrm{~h}$, these cells were subjected to the cell viability assay based on water soluble tetrazolium salts (WST)-8. Live cells were counted using a Cell Counting Kit (Dojindo Laboratories, Kumamoto, Japan).

Statistical analysis. For miRNA array-based analyses, the signal intensity ratio and $\log 2$ ratio of each plasma miRNA were calculated by the ratio of PCa patients to healthy volunteers. 
The Mann-Whitney $U$-test for unpaired data from plasma or tissue samples was performed. The Kruskal-Wallis $H$-test was also used to compare more than two groups. The Wilcoxon test was used to compare the paired plasma samples obtained before and 1 month after pancreatectomy. The Chi-square test or Fisher's exact probability test was used to evaluate correlations between the results of plasma miRNA levels and clinicopathological factors. A $P$-value $<0.05$ was considered statistically significant.

Receiver-operating characteristic (ROC) curves and the area under the ROC curve (AUC) were used to assess the feasibility of using plasma miRNA as a diagnostic tool for detecting PCa. The Youden index was used to determine the cutoff value for the plasma miRNAs levels (Akobeng, 2007). For the analysis of survival rates, Kaplan-Meier survival curves were constructed for groups based on univariate predictors, and differences between the groups were analysed with the log-rank test or Wilcoxon test. Univariate and multivariate survival analyses were performed using the likelihood ratio test of the stratified Cox proportional hazards model. A $P$-value $<0.05$ was considered statistically significant.

\section{RESULTS}

Study design to find novel plasma miRNA biomarkers for PCa. This study was designed as follows: (1) Selection of appropriate miRNA candidates based on the comparison of expression levels in plasma between PCa patients and healthy volunteers using the Toray 3D-Gene microRNA array-based approach; (2) Small-scale analysis of plasma samples using qRT-PCR to validate the utility of the selected miRNA candidates;
(3) Evaluation of whether the plasma level of miR-744 reflects tumour dynamics during the treatment of PCa patients; (4) Largescale analysis to validate the plasma level of miR-744 using two independent cohorts; (5) Analysis of how the plasma level of miR-744 is associated with the clinicopathological characteristics of PCa patients and with the prognosis of patients with curative resection and non-operable patients with chemotherapeutic treatment; and (6) Evaluation of whether the miR-744 overexpression in PCa cells induced chemoresistance to gemcitabine in vitro (Figure $1 \mathrm{~A})$.

Selection of plasma miRNA candidates from the comprehensive miRNA array-based approach. Using a miRNA array-based approach, we selected miRNA candidates for cancer detection based on comparison of the plasma levels of each miRNA between PCa patients and healthy volunteers (Figure 1B). Of the 1719 candidates analysed, the expression levels of 262 plasma miRNAs, which were higher in PCa patients than in healthy volunteers (Supplementary Table S1). In order to find more sensitive biomarkers, we focussed on 20 miRNAs with the highest expression levels in the plasma of PCa patients (Figure 1B). Of these 20 miRNAs, we selected seven miRNAs, miR-615-5p, $-744,-223,-575,-557,-675$, and -550 a, which were previously reported to have an oncogenic role because our previous studies revealed that high plasma level of oncogenic miRNAs had a high possibility to be derived from tumour necrosis, apoptosis, and active release of secretory vesicles such as exosome from cancer cells, and thereby these miRNAs in plasma could reflect tumour dynamics in cancer tissues (Tsujiura et al, 2010; Komatsu et al, 2011; Kawaguchi et al, 2013; Komatsu et al, 2014), whereas tumour-suppressive miRNAs and functionally unknown miRNAs
A

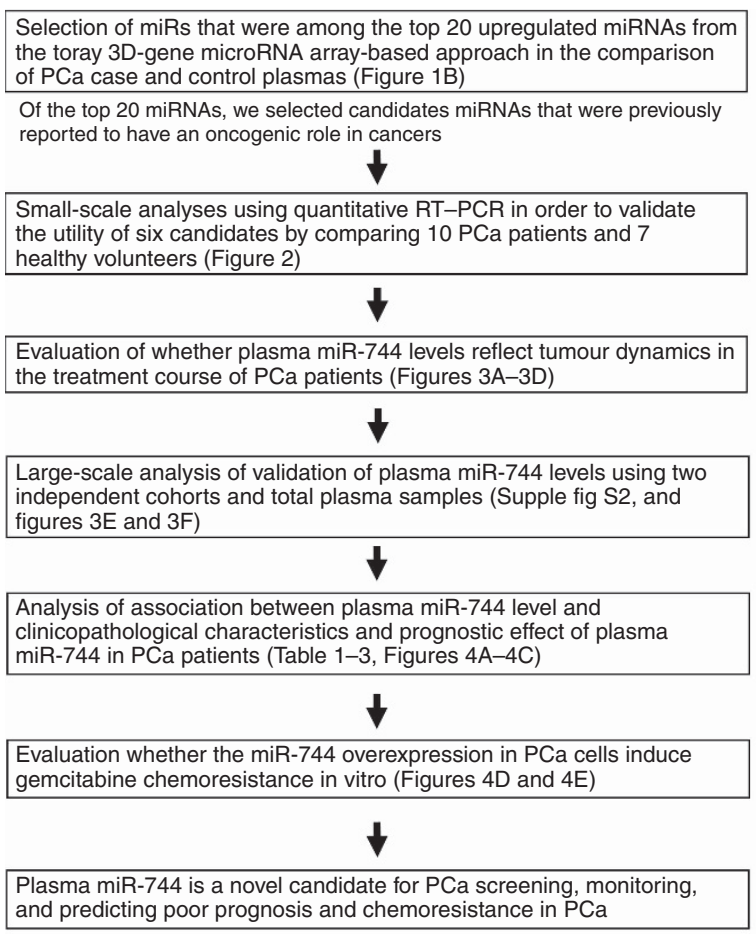

B

\begin{tabular}{|c|c|c|c|c|c|c|c|}
\hline \multirow{2}{*}{\multicolumn{2}{|c|}{ Rank }} & \multirow[b]{2}{*}{ Gene ID } & \multirow[b]{2}{*}{ Gene function } & \multicolumn{2}{|c|}{ Signal intensity } & \multicolumn{2}{|c|}{ Fold changes } \\
\hline & & & & Pca & volunteer & $\mathrm{PCa} /$ volunteer & Log2 ratio \\
\hline P & 1 & hsa-miR-615-5p & Oncogenic & 176.4 & 18.1 & 9.75 & 3.28 \\
\hline & 2 & hsa-miR-3,679-5p & Unknown & 105.5 & 24.5 & 4.31 & 2.11 \\
\hline & 3 & hsa-miR-574-3p & Unknown & 67.1 & 15.7 & 4.28 & 2.10 \\
\hline & 4 & hsa-miR-187* & Suppressive & 394.4 & 93.6 & 4.21 & 2.07 \\
\hline & 5 & hsa-miR-548I & Unknown & 68.7 & 16.7 & 4.13 & 2.04 \\
\hline$\bullet$ & 6 & hsa-miR-744 & Oncogenic & 203.7 & 49.7 & 4.10 & 2.03 \\
\hline ○ & 7 & hsa-miR-223 & Oncogenic & 97.5 & 24.2 & 4.03 & 2.01 \\
\hline $\boldsymbol{b}$ & 8 & hsa-miR-575 & Oncogenic & 171.6 & 43.0 & 3.99 & 2.00 \\
\hline & 9 & hsa-miR-3,940-3p & Unknown & 56.6 & 14.8 & 3.84 & 1.94 \\
\hline $\boldsymbol{b}$ & 10 & hsa-miR-557 & Oncogenic & 167.0 & 46.8 & 3.57 & 1.84 \\
\hline & 11 & hsa-miR-675 & Oncogenic & 90.6 & 25.6 & 3.54 & 1.82 \\
\hline & 12 & hsa-miR-1,587 & Unknown & 71.0 & 21.2 & 3.35 & 1.74 \\
\hline & 13 & hsa-miR-1,225-3p & Unknown & 52.4 & 15.8 & 3.32 & 1.73 \\
\hline & 14 & hsa-miR-1,275 & Suppressive & 230.7 & 71.5 & 3.23 & 1.69 \\
\hline & 15 & hsa-miR-675* & Unknown & 50.1 & 15.6 & 3.22 & 1.69 \\
\hline & 16 & hsa-miR-4,294 & Unknown & 2204.4 & 691.8 & 3.19 & 1.67 \\
\hline & 17 & hsa-miR-4,271 & Unknown & 105.1 & 33.3 & 3.16 & 1.66 \\
\hline & 18 & hsa-let-7i & Suppressive & 48.4 & 15.4 & 3.15 & 1.65 \\
\hline & 19 & hsa-miR-4,446-3p & Unknown & 149.8 & 47.6 & 3.15 & 1.65 \\
\hline ○ & 20 & hsa-miR-550a & Oncogenic & 43.8 & 14.3 & 3.07 & 1.62 \\
\hline
\end{tabular}

Figure 1. Study design and selection of plasma miRNA candidates. (A) Study design to find novel plasma miRNA biomarkers for PCa. (B) Selection of plasma miRNA candidates from the comprehensive miRNA array-based approach. Using the miRNA array-based approach to compare plasma miRNA levels between PCa patients and healthy volunteers, novel miRNA candidates for cancer detection were selected. Of the top 20 upregulated miRNAs in PCa, 7 novel candidate miRNAs, which were previously reported to have an oncogenic role in cancers, were selected. Of these, six miRNAs (closed circle) excluding miR-223 (open circle) were selected for further analysis, because miR-223 is still not known well enough to be suitable as a plasma biomarker (Pritchard et al, 2012). 
were excluded in this study because the origin of these miRNAs is not well known (Konishi et al, 2012). Concerning plasma miR-223, the origin of the high level of plasma miR-223 is currently uncertain in cancers, because miR-223 is possibly a myeloid- or platelet-derived miRNA (Pritchard et al, 2012; Cheng et al, 2013). In this study, therefore, we also excluded miR-223 from further analyses, because plasma miR-223 needs considerable specific investigation, and it is still not suitable to be a blood-based
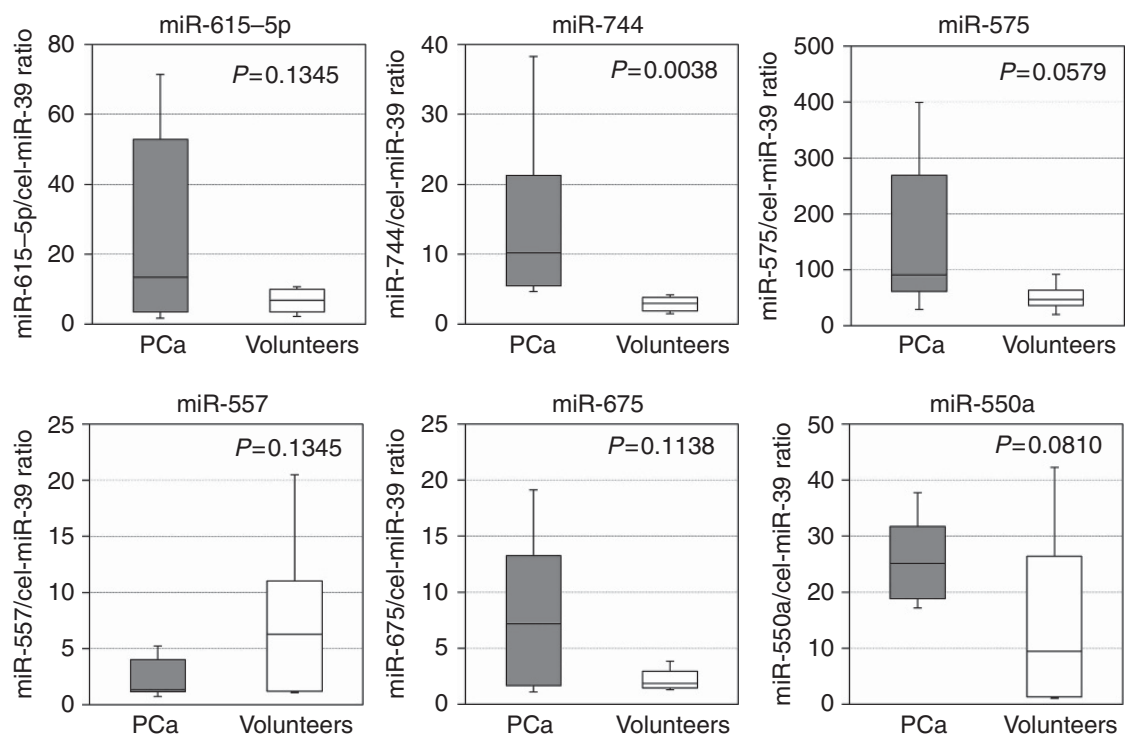

Figure 2. Small-scale analyses comparing plasma levels of six miRNAs between PCa patients and healthy volunteers. Plasma levels of the selected 6 miRNAs in 10 PCa patients and 7 healthy volunteers were analysed by qRT-PCR. The expression level of each miRNA was normalised to that of cel-miR-39 as described in Materials and Methods.

A

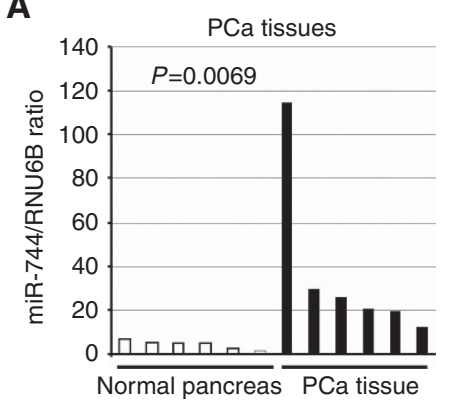

B

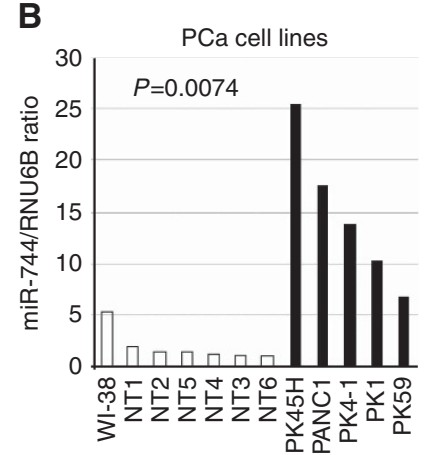

C

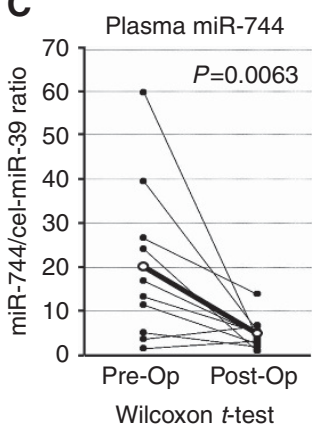

D

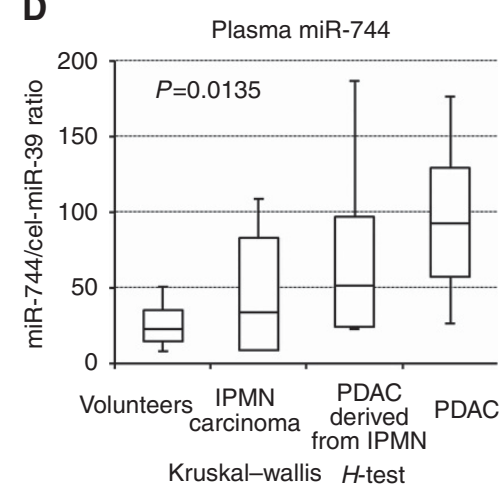

$\mathbf{F}$

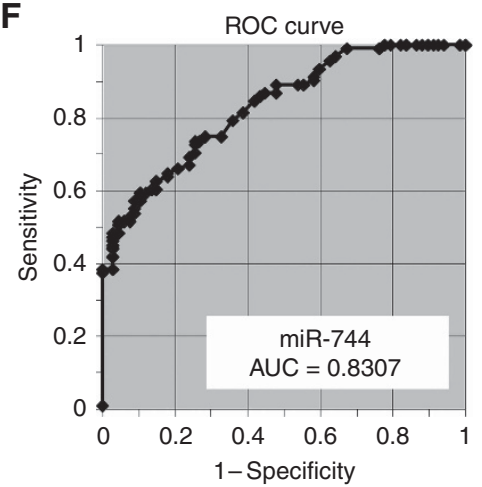

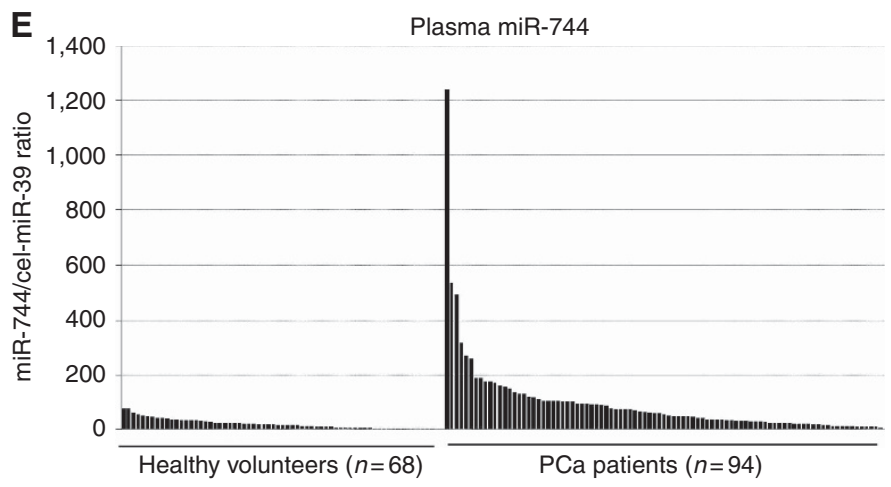

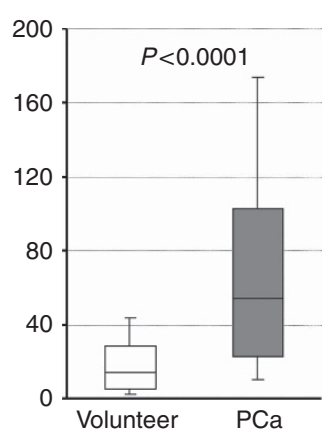

Figure 3. The expression level of miR-744 in PCa tissues, PCa cell lines, and plasma of PCa patients. (A and B) miR-744 expression was significantly higher in PCa tissues $(P=0.0069)$ and PCa cell lines $(P=0.0074)$ than in normal tissues and fibroblasts, respectively. (C) The plasma level of miR-744 was significantly lower in PCa patients after surgery than before surgery. (D) A higher level of plasma miR-744 is associated with histopathologically more malignant subtypes of pancreatic neoplasm, such as normal tissue, IPMN carcinoma, PDAC-derived IPMN, and PDAC. (E) miR-744 was more highly expressed in the plasma of PCa patients than in that of healthy volunteers. For a large-scale analysis, total RNA extracted from plasmas of 94 PCa patients and 68 age-matched healthy volunteers were used to analyse the expression level of miR-744 using qRT-PCR. (F) Analysis of receiver-operating characteristic (ROC) curve to detect PCa patients. ROC analysis showed the greatest AUC of 0.8307 for miR-744. 
biomarker for cancer detection and tumour monitoring at present. Currently, these issues are under evaluation.

Small-scale analysis of plasma levels of six miRNAs in PCa patients and healthy volunteers. We next investigated the plasma levels of the selected six miRNAs in 10 PCa patients and 7 health volunteers by qRT-PCR using small-scale analysis. As indicated in the results from the miRNA array-based approach, the expression levels of miR-744 $(P=0.0038)$ was validated to be the most significant, and miR-615-5p $(P=0.1345)$, miR-575 $(P=0.0579)$, miR-675 $(P=0.1138)$, and miR-550a $(P=0.0810)$ tended to be higher in the plasma of PCa patients than that of healthy volunteers, whereas plasma miR-557 $(P=0.1345)$ tended to be lower in the PCa patients (Figure 2). We, therefore, selected miR-744 for further analyses.

Evaluation of the association between the plasma level of miR744 and tumour dynamics. After confirming the higher level of plasma miR-744 in PCa patients, we next examined the expression level of miR-744 in primary PCa tissues and PCa cell lines. We used qRT-PCR to determine the expression of miR-744 in six $\mathrm{PCa}$ tissues and six normal pancreatic tissues (Figure 3A, Supplementary Figure S1A), as well as in the human PCa cell lines, PK-1, KP4-1, PK-45H, PK-59, and PANC-1, and a human fibroblast cell line, WI-38 (Figure 3B, Supplementary Figure S1B). The miR-744 expression level was significantly higher in $\mathrm{PCa}$ tissues than in normal pancreatic tissues $(P=0.0069$; Figure $3 \mathrm{~A})$. A similar result was observed in the $\mathrm{PCa}$ cell lines in comparison with the fibroblast cell line and the normal pancreatic tissues ( $P=0.0074$; Figure $3 \mathrm{~B})$. To validate whether the plasma level of miR-744 reflects tumour dynamics during the treatment of $\mathrm{PCa}$ patients, we evaluated the plasma level of miR-744 in paired samples that were collected before and almost 1 month after surgery from $10 \mathrm{PCa}$ patients who underwent curative pancreatectomy, and we observed that miR-744 was significantly reduced in postoperative plasma samples $(P=0.0063$; Figure $3 \mathrm{C})$. These results indicate that the plasma level of miR-744 could be used to trace tumour dynamics in PCa patients.

Large-scale analysis of the plasma level of miR-744 in PCa patients. We next validated our observations in large-scale settings. Before analysing a large number of samples by qRT-PCR, the linearity of qRT-PCR was confirmed by various concentrations of $1-0.0001 \mathrm{fmol}$ of each synthetic miRNA, namely miR-744 $\left(R^{2}=0.9924\right)$ and cel-miR-39 $\left(R^{2}=0.9952\right)$, between the logarithm of the amount of input miRNA and $\mathrm{Ct}$ values (Supplementary Figure S2). Plasma miR-744 was detectable in all samples from $94 \mathrm{PCa}$ patients and 68 healthy volunteers. Using two independent cohorts, we observed that the plasma level of miR-744 was significantly higher in the PCa patients than in the healthy volunteers $(P<0.0001$; Supplementary Figure S3). A waterfall plot also demonstrated a similar result $(P<0.0001$; Figure 3E). Recent reports demonstrated that some circulating miRNAs may be derived from peripheral blood cells (Pritchard et al, 2011). In this study, no significant correlation was observed between the plasma level of miR-744 and the number of any type of peripheral blood cells (Supplementary Figure S4). Furthermore, to detect any cutoff points that could differentiate cancer patients from healthy volunteers, we utilised the AUC with the Youden index (Akobeng, 2007; Figure 3F) and calculated that the value for the AUC was 0.8307. The optimal cutoff point was indicated at 44.0 in relative expression using the miR-744/cel-miR-39 ratio with a sensitivity of $59.3 \%$, a specificity of $89.6 \%$, and an accuracy of $72.2 \%$. Our results provide evidence that the plasma level of miR-744 can be used to distinguish PCa patients from healthy volunteers to a clinically satisfactory degree in comparison to conventional tumour markers.
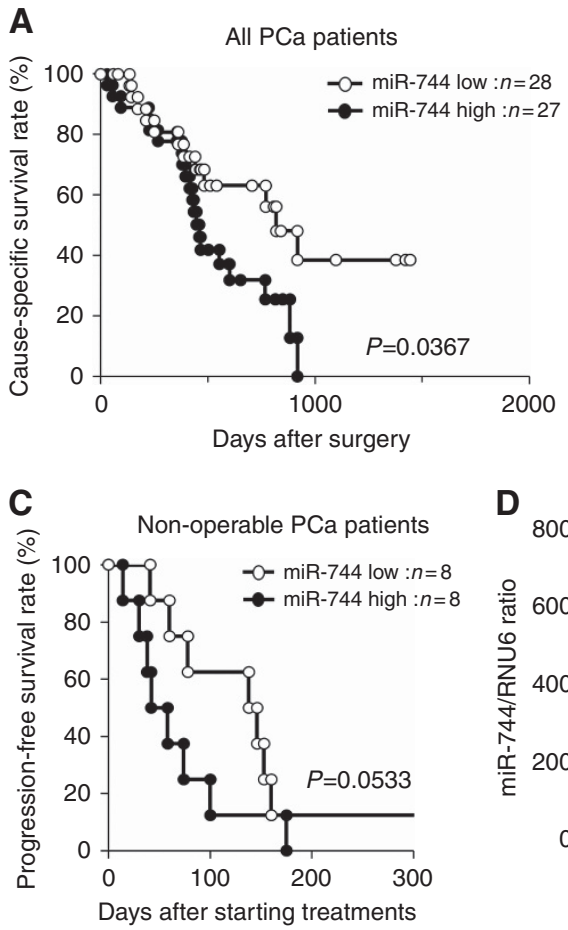
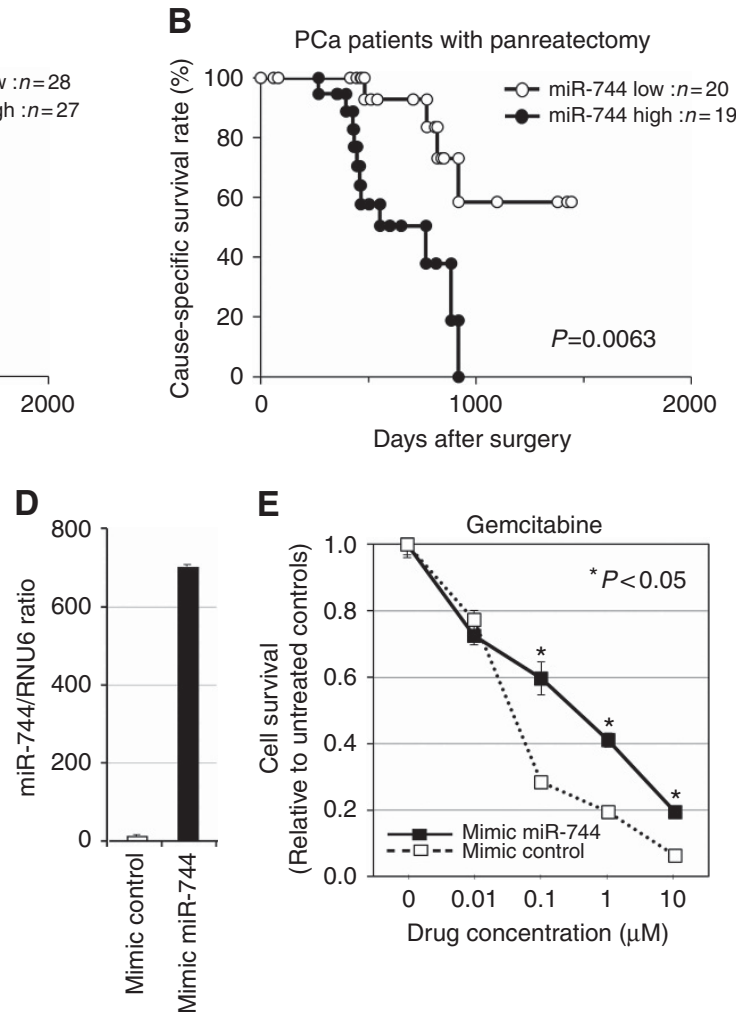

E

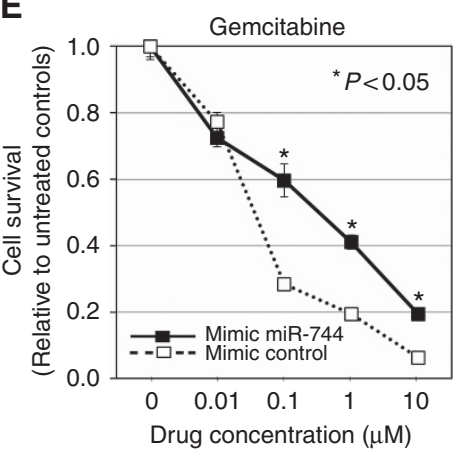

Figure 4. A higher level of plasma miR-744 is associated with a worse prognosis of PCa patients in the first cohort study. (A) Case-specific survival curves of all PCa patients. (B) Case-specific survival curves of PCa patients with pancreatectomy. (C) Progression-free survival curves of nonoperable PCa patients. ( $D$ and $\mathbf{E}$ ) Overexpression of miR-744 was associated with decreased chemosensitivity to the gemcitabine treatment in PCa. Overexpression of miR-744 reduces chemosensitivity to gemcitabine in the KP4-1 cell line. 
Correlation between the plasma level of miR-744 and clinicopathological factors in PCa patients. We analysed whether the plasma level of miR-744 and clinicopathological factors are correlated in $\mathrm{PCa}$ patients. In all $94 \mathrm{PCa}$ patients, advanced T-stage was the only factor that was correlated with a high level of plasma miR-744 $(P=0.0059$; Table 1$)$. In two independent cohorts, a high level of plasma miR-744 was correlated with advanced T-stage (first cohort: $P=0.0058$, second cohort: $P=0.1976)$ and the histological type of invasive ductal adenocarcinoma (first cohort: $P=0.0115$, second cohort: $P=0.0534$; Supplementary Table S2). Detail distributions of patients with each T-stage and plasma miR-744 level are shown in Supplementary Table S3. In this study, there was no resected case with the locally advanced T4 tumour, which was defined as the tumour invading to the celiac axis and/or the super mesenteric artery (Sobin and Compton, 2010). We observed that PCa patients with high levels of plasma miR-744 tended to have progressive invasiveness from intraductal papillary mucinous neoplasm (IPMN) carcinoma to pancreatic ductal adenocarcinoma (PDAC; Figure 3D).

Potential utility of miR-744 as a prognostic biomarker in the plasma of PCa patients. Moreover, the results of the first cohort revealed that a high level of plasma miR-744 was significantly associated with a worse cause-specific survival rate in all $\mathrm{PCa}$ patients $(P=0.0367$; Figure $4 \mathrm{~A})$ and in $\mathrm{PCa}$ patients with curative pancreatectomy $(P=0.0063$; Figure $4 \mathrm{~B})$. After pancreatectomy, patients with a high level of plasma miR-744 experienced more frequent lymph node metastasis $(P=0.0407)$ and recurrences $(P=0.0376$; Table 2$)$. We then performed univariate and multivariate analyses for cause-specific survival rate in PCa patients after curative pancreatectomy (Table 3). Univariate analysis showed that PDAC of histological type, lymph node metastasis, and a high level of plasma miR-744 were significant prognostic factors. In addition, multivariate analysis using the Cox proportional hazard regression model revealed that a high level of miR-744 was an independent factor predicting the poor prognosis of PCa patients $(P=0.0007$, hazard ratio: 21.2 (95\% CI: 3.17-436)).

Correlation between high expression level of miR-744 and chemoresistance to gemcitabine. Finally, we examined the correlation between the high level of miR-744 and chemoresistance to gemcitabine. Of non-operable PCa patients who were treated with chemo regimens that includes gemcitabine, those with high levels of miR-744 tended to have a worse progression-free survival rate $(P=0.0533$; Figure $4 \mathrm{C})$. To determine the effects of overexpression of miR-744 on chemoresistance to gemcitabine, KP4-1 cells were transfected with miR-744 mimics. After confirming the overexpression of miR-744 (Figure 4D), the transfected KP4-1 cells were then treated with increasing concentrations of gemcitabine, and cell viability was measured using the WST-8 assay. The viability of KP4-1 cells transfected with the control mimics was markedly inhibited by gemcitabine, whereas the inhibitory effect of gemcitabine was significantly reduced in miR-744-transfected KP4-1 cells (Figure 4E).

\section{DISCUSSION}

Development of minimally invasive biomarker assays for the early detection and effective clinical management of PCa patients is urgently required to reduce the high morbidity and mortality associated with this lethal disease. In recent years, many miRNAs have been identified as potential biomarkers of various cancers. Several researchers, including us, demonstrated that miRNAs that are circulating in plasma/serum of PCa patients are useful in detecting cancer because of a difference in their expression levels that distinguishes cancer patients from healthy individuals (Wang et al, 2009; Ho et al, 2010; Morimura et al, 2011;
Table 2. Association between plasma miR-744 levels and clinicopathological characteristics in $\mathrm{PCa}$ patients with pancreatectomy

\begin{tabular}{|c|c|c|c|c|}
\hline & & $\begin{array}{r}\text { Plasma } \\
\text { conce }\end{array}$ & $\begin{array}{l}\text { iR-744 } \\
\text { ation }\end{array}$ & Univariate $^{a}$ \\
\hline & $n$ & High & Low & $P$-value \\
\hline Total & 39 & 19 & 20 & \\
\hline Age & & & & 0.4254 \\
\hline $\begin{array}{l}<65 \\
>66\end{array}$ & $\begin{array}{l}19 \\
20\end{array}$ & $\begin{array}{r}11(58 \%) \\
8(42 \%)\end{array}$ & $\begin{array}{r}8(40 \%) \\
12(60 \%)\end{array}$ & \\
\hline Sex & & & & 0.2668 \\
\hline $\begin{array}{l}\text { Male } \\
\text { Female }\end{array}$ & $\begin{array}{l}13 \\
16\end{array}$ & $\begin{array}{r}9(47 \%) \\
10(53 \%)\end{array}$ & $\begin{array}{r}14(70 \%) \\
6(30 \%)\end{array}$ & \\
\hline Histological type & & & & 0.5587 \\
\hline $\begin{array}{l}\text { IPMN carcinoma } \\
\text { PDAC derived from IPMN } \\
\text { PDAC }\end{array}$ & $\begin{array}{r}10 \\
6 \\
23\end{array}$ & $\begin{array}{r}3(16 \%) \\
3(16 \%) \\
13(68 \%)\end{array}$ & $\begin{array}{r}7(35 \%) \\
3(15 \%) \\
10(50 \%)\end{array}$ & \\
\hline pT (TNM) & & & & 0.1552 \\
\hline $\begin{array}{l}\text { T1-2 } \\
\text { T3-4 }\end{array}$ & $\begin{array}{l}11 \\
28\end{array}$ & $\begin{array}{r}3(16 \%) \\
16(84 \%)\end{array}$ & $\begin{array}{r}8(40 \%) \\
12(60 \%)\end{array}$ & \\
\hline pN (TNM) & & & & 0.0407 \\
\hline $\begin{array}{l}\text { N0 } \\
\text { N1 }\end{array}$ & $\begin{array}{l}27 \\
12\end{array}$ & $\begin{array}{r}10(53 \%) \\
9(47 \%)\end{array}$ & $\begin{array}{r}17(85 \%) \\
3(15 \%)\end{array}$ & \\
\hline pStage (TNM) & & & & 0.3501 \\
\hline $\begin{array}{l}0-I I \\
I I I-I V\end{array}$ & $\begin{array}{l}12 \\
27\end{array}$ & $\begin{array}{r}4(21 \%) \\
15(79 \%)\end{array}$ & $\begin{array}{r}8(40 \%) \\
12(60 \%) \\
\end{array}$ & \\
\hline Recurrence & & & & 0.0376 \\
\hline $\begin{array}{l}\text { Absent } \\
\text { Present }\end{array}$ & $\begin{array}{l}20 \\
19\end{array}$ & $\begin{array}{r}6(32 \%) \\
13(68 \%) \\
\end{array}$ & $\begin{array}{r}14(70 \%) \\
6(30 \%) \\
\end{array}$ & \\
\hline $\begin{array}{l}\text { Abbreviations: IPMN = intraductal } \\
\text { PDAC = pancreatic ductal adenod } \\
\text { values are in bold. } \\
\text { a Chi-square test. }\end{array}$ & pillata & ucinous nec & $\mathrm{m} ; \mathrm{PCa}=\mathrm{p}$ & $\begin{array}{l}\text { creatic cancer; } \\
\text { asis. Significant }\end{array}$ \\
\hline
\end{tabular}

Liu et al, 2012; Kawaguchi et al, 2013). To date, however, there are only three reports on prognosis for miR-21, miR-1290, miR-486, and miR-196a (Kong et al, 2011; Liu et al, 2012; Li et al, 2013) and only one report on chemoresistance for miR-21 (Wang et al, 2013). This prompted us to find more clinically useful miRNAs, which might facilitate better decision making for PCa treatment.

In this study, we identified a plasma miRNA, miR-744, as a novel biomarker for $\mathrm{PCa}$, through genome-wide miRNA profiling of the plasma of PCa patients using high-resolution miRNA arrays. The expression level of plasma miR-744 was significantly higher in PCa patients than in healthy volunteers, and this finding was validated in small-scale analysis, two independent cohort analyses, and large-scale analysis (AUC 0.831). Moreover, miR-744 expression was significantly higher in PCa tissues and PCa cell lines than in normal tissues and fibroblasts, respectively. Preoperative plasma level of miR-744 was significantly reduced in postoperative samples. These findings indicate that miR-744 could contribute to screening $\mathrm{PCa}$ and monitoring tumour dynamics. However, regarding early detection of $\mathrm{PCa}$, a more sensitive miRNA in plasma such as miR-18a (AUC 0.936), which we previously reported (Morimura et al, 2011), or combination of miR-744 and other miRNAs might be useful because plasma miR-744 level was higher in patients with advanced PCa than that with early PCa.

Regarding the predictive value of malignant potential and prognosis, plasma miR-744 may have an excellent clinical value in comparison to previous reported plasma/serum miRNAs, including our own (Kong et al, 2011; Liu et al, 2012; Kawaguchi et al, 2013; Li et al, 2013). Namely, a high level of plasma miR-744, which was significantly correlated with lymph node metastasis and 
Table 3. Univariate and multivariate analyses for survival of PCa patients following pancreatectomy using the Cox's proportional hazard model

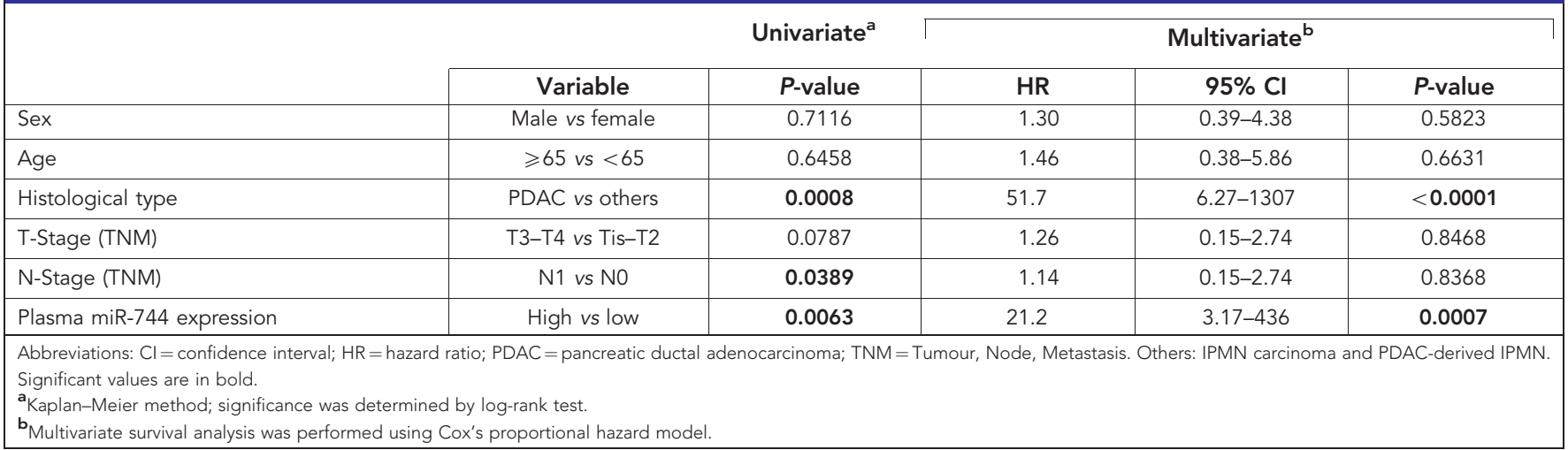

recurrences, was an independent poor prognostic factor of $\mathrm{PCa}$ patients after pancreatectomy $(P=0.0007$, HR $21.2(3.17-436))$. Furthermore, a high level of plasma miR-744 contributed to poorer progression-free survival of non-operable $\mathrm{PCa}$ patients who underwent gemcitabine-based chemotherapy. These finding strongly suggested the clinical utility of plasma miR-744 level in predicting malignant potential, prognosis, and chemoresistance, although the detailed mechanisms of its prognostic effects and chemoresistance have not fully been elucidated yet.

Concerning molecular function of miR-744, some recent studies reported that miR-744 is more highly expressed in head and neck cancer (Nurul-Syakima et al, 2011) and has a proliferative effect on prostate cancer cells through overexpression of cyclin B1 (Huang et al, 2012) and on nasopharyngeal carcinoma by directly interacting with ARHGAP5 (Rho GTPase activating protein 5; Fang et al, 2015). Whereas other reports showed an inhibitory effect of miR-744 on the proliferation of breast cancer cells (Vislovukh et al, 2013), a sensitising effect of miR-744-3p to ionising radiation on prostate cancer although that is only analysed in vitro, (Hatano et al, 2015) and better clinical outcomes of overexpressed miR-744 in hepatocellular carcinoma (Tan et al, 2015), Therefore, we specifically examined the molecular effect of overexpression of miR-744 on chemoresistance to gemcitabine and KP4-1 cells were transfected with miR-744 mimics. The viability of KP4-1 cells transfected with the control mimics was markedly inhibited by gemcitabine, whereas the inhibitory effect of gemcitabine was significantly reduced in miR-744-transfected KP4-1 cells; these supporting our clinical data of plasma miR744 in PCa patients undergoing gemcitabine-based chemotherapy.

Furthermore, in this study, we demonstrated that the plasma level of miR-744 could sensitively reflect the progressive extent of invasiveness in IPMN (Figure 3D). Namely, the plasma level of miR-744 might have a great potential to distinguish between IPMN carcinoma and PDAC-derived IPMN or between PDAC-derived IPMN and PDAC. The branch duct-type IPMN is normally followed without surgery unless the imaging diagnosis and the tumour size demands the surgical criteria for putative malignancy. To date, however, there is no highly sensitive biomarker to predict the malignancy in patients with branch duct-type IPMN. Plasma miR-744 may be useful for evaluating the malignant potential of IPMN or the invasiveness of PCa before surgery to make correct clinical decisions.

From viewpoints of liquid biopsy using blood miRNAs, previous studies revealed that the majority of circulating miRNAs co-fractionate with plasma protein complexes (Arroyo et al, 2011). Because plasma includes more abundant proteins, such as coagulation factors, than does serum, the miRNA profiles in the plasma of PCa patients were considerably different from those in the serum of PCa patients (Figure 1 and Supplementary Table S1; Li et al, 2013), which is similar to a case of oesophageal cancer (Takeshita et al, 2013; Komatsu et al, 2014). However, the expression levels of miR-744 in PCa patients were significantly higher than those in healthy volunteers in both plasma and serum, and the expression levels of miR-744 was high compared with those of other miRNAs (Figure 1 and Supplementary Table S1; $\mathrm{Li}$ et al, 2013). One of the reasons that miR-744 could be present in a remarkably stable form in plasma/serum might be that miR-744 is reported to be packaged by secretory particles, such as exosomes (Arroyo et al, 2011). These data strongly suggest that miR-744 could be reproducibly detectable in both plasma and serum and could be promising miRNAs in clinical settings of PCa treatment.

This is the first report to demonstrate the utility of plasma miR-744 among cancers. Because many issues must still be addressed before these findings can be translated into a clinically useful and non-invasive screening strategy for PCa patients, we will prospectively confirm the usefulness of plasma miR-744 in a larger number of patients. Furthermore, we believe that more sensitive plasma miRNAs could be identified as biomarkers for monitoring PCa using different strategies, such as next-generation sequencing or digital PCR-based approaches. These strategies are currently under evaluation and are expected to be reported upon in the near future.

\section{ACKNOWLEDGEMENTS}

We cordially appreciate Momoko Todo, MD (Kyoto Second Red Cross Hospital, Kyoto, Japan) for supporting our research.

\section{CONFLICT OF INTEREST}

The authors declare no conflict of interest.

\section{AUTHOR CONTRIBUTIONS}

MM and KS designed the research, analysed the data, and wrote the paper. All the authors performed the research.

\section{REFERENCES}

Akobeng AK (2007) Understanding diagnostic tests 3: receiver operating characteristic curves. Acta Paediatr 96: 644-647. 
Arroyo JD, Chevillet JR, Kroh EM, Ruf IK, Pritchard CC, Gibson DF, Mitchell PS, Bennett CF, Pogosova-Agadjanyan EL, Stirewalt DL, Tait JF, Tewari M (2011) Argonaute2 complexes carry a population of circulating microRNAs independent of vesicles in human plasma. Proc Natl Acad Sci USA 108: 5003-5008.

Calin GA, Croce CM (2006) MicroRNA signatures in human cancers. Nat Rev Cancer 6: 857-866.

Chen X, Ba Y, Ma L, Cai X, Yin Y, Wang K, Guo J, Zhang Y, Chen J, Guo X, Li Q, Li X, Wang W, Zhang Y, Wang J, Jiang X, Xiang Y, Xu C, Zheng P, Zhang J, Li R, Zhang H, Shang X, Gong T, Ning G, Wang J, Zen K, Zhang J, Zhang CY (2008) Characterization of microRNAs in serum: a novel class of biomarkers for diagnosis of cancer and other diseases. Cell Res 18: 997-1006.

Cheng HH, Mitchell PS, Kroh EM, Dowell AE, Chery L, Siddiqui J, Nelson PS, Vessella RL, Knudsen BS, Chinnaiyan AM, Pienta KJ, Morrissey C, Tewari M (2013) Circulating microRNA profiling identifies a subset of metastatic prostate cancer patients with evidence of cancer-associated hypoxia. PLoS One 8: e69239.

Cocucci E, Racchetti G, Meldolesi J (2009) Shedding microvesicles: artefacts no more. Trends Cell Biol 19: 43-51.

Fang Y, Zhu X, Wang J, Li N, Li D, Sakib N, Sha Z, Song W (2015) MiR-744 functions as a proto-oncogene in nasopharyngeal carcinoma progression and metastasis via transcriptional control of ARHGAP5. Oncotarget 6: 13164-13175.

Filipowicz W, Bhattacharyya SN, Sonenberg N (2008) Mechanisms of post-transcriptional regulation by microRNAs: are the answers in sight? Nat Rev Genet 9: 102-114.

Giovannetti E, van der Velde A, Funel N, Vasile E, Perrone V, Leon LG, De Lio N, Avan A, Caponi S, Pollina LE, Galla V, Sudo H, Falcone A, Campani D, Boggi U, Peters GJ (2012) High-throughput microRNA (miRNAs) arrays unravel the prognostic role of MiR-211 in pancreatic cancer. PLoS One 7: e49145.

Hasselmann DO, Rappl G, Tilgen W, Reinhold U (2001) Extracellular tyrosinase mRNA within apoptotic bodies is protected from degradation in human serum. Clin Chem 47: 1488-1489.

Hatano K, Kumar B, Zhang Y, Coulter JB, Hedayati M, Mears B, Ni X, Kudrolli TA, Chowdhury WH, Rodriguez R, DeWeese TL, Lupold SE (2015) A functional screen identifies miRNAs that inhibit DNA repair and sensitize prostate cancer cells to ionizing radiation. Nucleic Acids Res 43: 4075-4086.

He L, He X, Lim LP, de Stanchina E, Xuan Z, Liang Y, Xue W, Zender L, Magnus J, Ridzon D, Jackson AL, Linsley PS, Chen C, Lowe SW, Cleary MA, Hannon GJ (2007) A microRNA component of the p53 tumour suppressor network. Nature 447: 1130-1134.

He L, Thomson JM, Hemann MT, Hernando-Monge E, Mu D, Goodson S, Powers S, Cordon-Cardo C, Lowe SW, Hannon GJ, Hammond SM (2005) A microRNA polycistron as a potential human oncogene. Nature 435 : $828-833$.

Heinemann V, Boeck S, Hinke A, Labianca R, Louvet C (2008) Meta-analysis of randomized trials: evaluation of benefit from gemcitabine-based combination chemotherapy applied in advanced pancreatic cancer. BMC Cancer 8: 82.

Hirajima S, Komatsu S, Ichikawa D, Takeshita H, Konishi H, Shiozaki A, Morimura R, Tsujiura M, Nagata H, Kawaguchi T, Arita T, Kubota T, Fujiwara H, Okamoto K, Otsuji E (2013) Clinical impact of circulating miR-18a in plasma of patients with oesophageal squamous cell carcinoma. Br J Cancer 108: 1822-1829.

Hirata K, Egawa S, Kimura Y, Nobuoka T, Oshima H, Katsuramaki T, Mizuguchi T, Furuhata T (2007) Current status of surgery for pancreatic cancer. Dig Surg 24: 137-147.

Ho AS, Huang X, Cao H, Christman-Skieller C, Bennewith K, Le Q-T, Koong AC (2010) Circulating miR-210 as a novel hypoxia marker in pancreatic cancer. Transl Oncol 3: 109-113.

Huang V, Place RF, Portnoy V, Wang J, Qi Z, Jia Z, Yu A, Shuman M, Yu J, Li LC (2012) Upregulation of Cyclin B1 by miRNA and its implications in cancer. Nucleic Acids Res 40: 1695-1707.

Ichikawa D, Komatsu S, Konishi H, Otsuji E (2012) Circulating microRNA in digestive tract cancers. Gastroenterology 142: 1074-1078e1071.

Jemal A, Siegel R, Ward E, Hao Y, Xu J, Thun MJ (2009) Cancer statistics, 2009. CA Cancer J Clin 59: 225-249.

Jones S, Zhang X, Parsons DW, Lin JC, Leary RJ, Angenendt P, Mankoo P, Carter H, Kamiyama H, Jimeno A, Hong SM, Fu B, Lin MT, Calhoun ES, Kamiyama M, Walter K, Nikolskaya T, Nikolsky Y, Hartigan J, Smith DR,
Hidalgo M, Leach SD, Klein AP, Jaffee EM, Goggins M, Maitra A, Iacobuzio-Donahue C, Eshleman JR, Kern SE, Hruban RH, Karchin R, Papadopoulos N, Parmigiani G, Vogelstein B, Velculescu VE, Kinzler KW (2008) Core signaling pathways in human pancreatic cancers revealed by global genomic analyses. Science 321: 1801-1806.

Kawaguchi T, Komatsu S, Ichikawa D, Morimura R, Tsujiura M, Konishi H, Takeshita H, Nagata H, Arita T, Hirajima S, Shiozaki A, Ikoma H, Okamoto K, Ochiai T, Taniguchi H, Otsuji E (2013) Clinical impact of circulating miR-221 in plasma of patients with pancreatic cancer. Br J Cancer 108: 361-369.

Komatsu S, Ichikawa D, Hirajima S, Kawaguchi T, Miyamae M, Okajima W, Ohashi T, Arita T, Konishi H, Shiozaki A, Fujiwara H, Okamoto K, Yagi N, Otsuji E (2014) Plasma microRNA profiles: identification of miR-25 as a novel diagnostic and monitoring biomarker in oesophageal squamous cell carcinoma. Br J Cancer 111: 1614-1624.

Komatsu S, Ichikawa D, Takeshita H, Konishi H, Nagata H, Hirajima S, Kawaguchi T, Arita T, Shiozaki A, Fujiwara H, Okamoto K, Otsuji E (2012) Prognostic impact of circulating miR-21 and miR-375 in plasma of patients with esophageal squamous cell carcinoma. Expert Opin Biol Ther 12(Suppl 1): S53-S59.

Komatsu S, Ichikawa D, Takeshita H, Tsujiura M, Morimura R, Nagata H, Kosuga T, Iitaka D, Konishi H, Shiozaki A, Fujiwara H, Okamoto K, Otsuji E (2011) Circulating microRNAs in plasma of patients with oesophageal squamous cell carcinoma. Br J Cancer 105: 104-111.

Kong X, Du Y, Wang G, Gao J, Gong Y, Li L, Zhang Z, Zhu J, Jing Q, Qin Y, Li Z (2011) Detection of differentially expressed microRNAs in serum of pancreatic ductal adenocarcinoma patients: miR-196a could be a potential marker for poor prognosis. Dig Dis Sci 56: 602-609.

Konishi H, Ichikawa D, Komatsu S, Shiozaki A, Tsujiura M, Takeshita H, Morimura R, Nagata H, Arita T, Kawaguchi T, Hirashima S, Fujiwara H, Okamoto K, Otsuji E (2012) Detection of gastric cancer-associated microRNAs on microRNA microarray comparing pre- and post-operative plasma. Br J Cancer 106: 740-747.

Kosaka N, Iguchi H, Ochiya T (2010) Circulating microRNA in body fluid: a new potential biomarker for cancer diagnosis and prognosis. Cancer Sci 101: 2087-2092

Lee RC, Feinbaum RL, Ambros V (1993) The C. elegans heterochronic gene lin-4 encodes small RNAs with antisense complementarity to lin-14. Cell 75: 843-854.

Li A, Yu J, Kim H, Wolfgang CL, Canto MI, Hruban RH, Goggins M (2013) MicroRNA array analysis finds elevated serum miR-1290 accurately distinguishes patients with low-stage pancreatic cancer from healthy and disease controls. Clin Cancer Res 19: 3600-3610.

Liu J, Gao J, Du Y, Li Z, Ren Y, Gu J, Wang X, Gong Y, Wang W, Kong X (2012) Combination of plasma microRNAs with serum CA19-9 for early detection of pancreatic cancer. Int J Cancer 131: 683-691.

Livak KJ, Schmittgen TD (2001) Analysis of relative gene expression data using real-time quantitative PCR and the 2(-Delta Delta $\mathrm{C}(\mathrm{T})$ ) Method. Methods 25: 402-408.

Lu J, Getz G, Miska EA, Alvarez-Saavedra E, Lamb J, Peck D, Sweet-Cordero A, Ebert BL, Mak RH, Ferrando AA, Downing JR, Jacks T, Horvitz HR, Golub TR (2005) MicroRNA expression profiles classify human cancers. Nature 435: 834-838.

Matsuno S, Egawa S, Fukuyama S, Motoi F, Sunamura M, Isaji S, Imaizumi T, Okada S, Kato H, Suda K, Nakao A, Hiraoka T, Hosotani R, Takeda K (2004) Pancreatic Cancer Registry in Japan: 20 years of experience. Pancreas 28: 219-230.

Mitchell PS, Parkin RK, Kroh EM, Fritz BR, Wyman SK, Pogosova-Agadjanyan EL, Peterson A, Noteboom J, O’Briant KC, Allen A, Lin DW, Urban N, Drescher CW, Knudsen BS, Stirewalt DL, Gentleman R, Vessella RL, Nelson PS, Martin DB, Tewari M (2008) Circulating microRNAs as stable blood-based markers for cancer detection. Proc Natl Acad Sci USA 105: 10513-10518.

Morimura R, Komatsu S, Ichikawa D, Takeshita H, Tsujiura M, Nagata H, Konishi H, Shiozaki A, Ikoma H, Okamoto K, Ochiai T, Taniguchi H, Otsuji E (2011) Novel diagnostic value of circulating miR-18a in plasma of patients with pancreatic cancer. Br J Cancer 105: 1733-1740.

Nagino K, Nomura O, Takii Y, Myomoto A, Ichikawa M, Nakamura F, Higasa M, Akiyama H, Nobumasa H, Shiojima S, Tsujimoto G (2006) Ultrasensitive DNA chip: gene expression profile analysis without RNA amplification. J Biochem 139: 697-703.

Nurul-Syakima AM, Yoke-Kqueen C, Sabariah AR, Shiran MS, Singh A, Learn-Han L (2011) Differential microRNA expression and identification 
of putative miRNA targets and pathways in head and neck cancers. Int J Mol Med 28: 327-336.

Ozaka M, Matsumura Y, Ishii H, Omuro Y, Itoi T, Mouri H, Hanada K, Kimura Y, Maetani I, Okabe Y, Tani M, Ikeda T, Hijioka S, Watanabe R, Ohoka S, Hirose Y, Suyama M, Egawa N, Sofuni A, Ikari T, Nakajima T (2012) Randomized phase II study of gemcitabine and S-1 combination versus gemcitabine alone in the treatment of unresectable advanced pancreatic cancer (Japan Clinical Cancer Research Organization PC-01 study). Cancer Chemother Pharmacol 69: 1197-1204.

Pfaffl MW (2001) A new mathematical model for relative quantification in real-time RT-PCR. Nucleic Acids Res 29: e45.

Pritchard CC, Kroh E, Wood B, Arroyo JD, Dougherty KJ, Miyaji MM, Tait JF, Tewari M (2011) Blood cell origin of circulating microRNAs: a cautionary note for cancer biomarker studies. Cancer Prev Res (Phila) 5 : 492-497.

Pritchard CC, Kroh E, Wood B, Arroyo JD, Dougherty KJ, Miyaji MM, Tait JF, Tewari M (2012) Blood cell origin of circulating microRNAs: a cautionary note for cancer biomarker studies. Cancer Prev Res (Phila) 5: 492-497.

Rechavi O, Erlich Y, Amram H, Flomenblit L, Karginov FV, Goldstein I, Hannon GJ, Kloog Y (2009) Cell contact-dependent acquisition of cellular and viral nonautonomously encoded small RNAs. Genes Dev 23: 1971-1979.

Satake K, Kanazawa G, Kho I, Chung YS, Umeyama K (1985) A clinical evaluation of carbohydrate antigen 19-9 and carcinoembryonic antigen in patients with pancreatic carcinoma. J Surg Oncol 29: 15-21.

Skog J, Wurdinger T, van Rijn S, Meijer DH, Gainche L, Sena-Esteves M, Curry Jr WT, Carter BS, Krichevsky AM, Breakefield XO (2008) Glioblastoma microvesicles transport RNA and proteins that promote tumour growth and provide diagnostic biomarkers. Nat Cell Biol 10: 1470-1476.

Sobin LH, Compton CC (2010) TNM seventh edition: what's new, what's changed: communication from the International Union Against Cancer and the American Joint Committee on Cancer. Cancer 116: 5336-5339.

Sultana A, Tudur Smith C, Cunningham D, Starling N, Neoptolemos JP, Ghaneh P (2008) Meta-analyses of chemotherapy for locally advanced and metastatic pancreatic cancer: results of secondary end points analyses. Br J Cancer 99: 6-13.

Takeshita N, Hoshino I, Mori M, Akutsu Y, Hanari N, Yoneyama Y, Ikeda N, Isozaki Y, Maruyama T, Akanuma N, Komatsu A, Jitsukawa M, Matsubara H (2013) Serum microRNA expression profile: miR-1246 as a novel diagnostic and prognostic biomarker for oesophageal squamous cell carcinoma. Br J Cancer 108: 644-652.

Tan YL, Bai ZG, Zou WL, Ma XM, Wang TT, Guo W, Liu J, Li JS, Jie Y, Zang YJ, Zhang ZT (2015) miR-744 is a potential prognostic marker in patients with hepatocellular carcinoma. Clin Res Hepatol Gastroenterol 39: 359-365.

Thayer SP, di Magliano MP, Heiser PW, Nielsen CM, Roberts DJ, Lauwers GY, Qi YP, Gysin S, Fernandez-del Castillo C, Yajnik V, Antoniu B, McMahon M, Warshaw AL, Hebrok M (2003) Hedgehog is an early and late mediator of pancreatic cancer tumorigenesis. Nature $\mathbf{4 2 5}$ : 851-856.

Tsujiura M, Ichikawa D, Komatsu S, Shiozaki A, Takeshita H, Kosuga T, Konishi H, Morimura R, Deguchi K, Fujiwara H, Okamoto K, Otsuji E (2010) Circulating microRNAs in plasma of patients with gastric cancers. Br J Cancer 102: 1174-1179.

Valadi H, Ekstrom K, Bossios A, Sjostrand M, Lee JJ, Lotvall JO (2007) Exosome-mediated transfer of mRNAs and microRNAs is a novel mechanism of genetic exchange between cells. Nat Cell Biol 9: 654-659.

Vickers KC, Palmisano BT, Shoucri BM, Shamburek RD, Remaley AT (2011) MicroRNAs are transported in plasma and delivered to recipient cells by high-density lipoproteins. Nat Cell Biol 13: 423-433.

Vislovukh A, Kratassiouk G, Porto E, Gralievska N, Beldiman C, Pinna G, El'skaya A, Harel-Bellan A, Negrutskii B, Groisman I (2013) Proto-oncogenic isoform A2 of eukaryotic translation elongation factor eEF1 is a target of miR-663 and miR-744. Br J Cancer 108: 2304-2311.

Wang J, Chen J, Chang P, LeBlanc A, Li D, Abbruzzesse JL, Frazier ML, Killary AM, Sen S (2009) MicroRNAs in plasma of pancreatic ductal adenocarcinoma patients as novel blood-based biomarkers of disease. Cancer Prev Res (Phila) 2: 807-813.

Wang P, Zhuang L, Zhang J, Fan J, Luo J, Chen H, Wang K, Liu L, Chen Z, Meng Z (2013) The serum miR-21 level serves as a predictor for the chemosensitivity of advanced pancreatic cancer, and miR-21 expression confers chemoresistance by targeting FasL. Mol Oncol 7: 334-345.

Yamamoto Y, Shimada K, Takeuchi Y, Sofue K, Shibamoto K, Nara S, Esaki M, Sakamoto Y, Kosuge T, Hiraoka N (2012) Assessment of the interface between retroperitoneal fat infiltration of pancreatic ductal carcinoma and the major artery by multidetector-row computed tomography: surgical outcomes and correlation with histopathological extension. World J Surg 36: 2192-2201.

This work is published under the standard license to publish agreement. After 12 months the work will become freely available and the license terms will switch to a Creative Commons AttributionNonCommercial-Share Alike 4.0 Unported License.

Supplementary Information accompanies this paper on British Journal of Cancer website (http://www.nature.com/bjc) 